\title{
THE FUTURE OF COUNTERVAILING MONETARY POWER
}

As we have seen, many emerging-market and developing countries (EMDs) were able to reregulate cross-border finance and to create more policy room to maneuver in global economic governance institutions. These significant changes in policy, however, did not result in significant enough economic outcomes to fully mitigate the surges and sudden stops of capital flows in the wake of the crisis. The domestic and international political forces that some countries were able to countervail are the reason that some nations were not able to regulate at home and why there is still inadequate policy space to regulate capital flows under the current system of global economic governance.

\section{Reregulation of Cross-Border Finance}

During the surges of capital flows that led to the financial crises of the 1990s, most EMDs either liberalized their capital account further or managed capital flows through less controversial means, such as intervening in the currency markets. If countries did put regulations in place on the inflow or outflow of capital, they were ridiculed by the International Monetary Fund (IMF), the US Treasury Department, and the financial press. The 2008 global financial crisis was a different matter. In the wake of the crisis, many EMDs reregulated cross-border finance to handle the surges in cross-border financial flows. Significantly, this time the international financial institutions and industrialized countries did not ridicule EMDs 
for taking such actions. In fact, many tacitly supported this new ad hoc regime in which the industrialized countries pursued loose monetary policies and EMDs buffered the harmful effects of such policies using capital account regulations.

Regulation enjoyed greater legitimacy in the eyes of the economics profession because of breakthroughs in economic thinking that now saw the regulation of capital flows as market-correcting mechanisms to achieve stability and growthnot as distortionary moves to defer necessary adjustment. Moreover, years of econometric analysis proved that capital account liberalization was not strongly correlated with economic growth and tended to trigger banking crises in nations that had weaker institutional frameworks. Economists were even modeling the regulation of capital flows and recommending that countries cooperate on regulation on both ends of the capital flow cycle. Pioneering economists such as Nelson Barbosa in Brazil, Hyun Song Shin in South Korea, Anton Korinek in the United States, and Jonathan Ostry at the IMF all translated this new thinking for their respective policymaking circles.

These control measures met with some success. Nations that had regulations in place when the global financial crisis occurred were among the least hard hit. And the majority of the research shows that countries that reregulated crossborder finance after the crisis were able to change the level of inflows, reduce exchange rate pressure, have a more autonomous monetary policy, and grow faster than countries that did not.

EMDs also sought to ensure that they had enough policy space to deploy such regulations under the global economic governance institutions. At the IMF, the BRICS coalition (Brazil, Russia, India, China, and South Africa) worked to defend the regime of cooperative decentralization, in which, under the IMF Articles of Agreement, member states may regulate capital flows as they see fit. At the G20, EMDs elevated the importance of regulating cross-border finance to the highest level by inserting it into communiqués and negotiating an explicit document granting legitimacy to reregulating capital flows. In the trading regime, a regime with strong international standards where some countries have moved the discussion of capital account liberalization, many EMDs have been less successful. Large countries such as Brazil have been able to avoid commitments under the General Agreement on Trade in Services (GATS) that make it harder to regulate capital flows, and countries that already have commitments may have recourse to exceptions under the World Trade Organization (WTO). In contrast, countries that have chosen to engage in free-trade agreements (FTAs) and bilateral investment treaties (BITs), especially with the United States, have traded away their ability to regulate cross-border finance without being subject to claims under those treaties. South Korea is an exception to this; it has been able to carve some of its regulations on capital flows out of its FTA. 
But these changes in domestic and global policy were not enough to significantly change economic outcomes. Yes, many EMDs would have been even worse off from the post-crisis surges and sudden stops of capital flows than if they hadn't regulated those flows. Still, the regulations had only a modest effect because of their lack of strength and the lack of cooperation between source (mostly, industrialized) countries and EMDs. The result was what Grabel (2011) refers to as productive incoherence, where many positive developments have been tempered by the lack of political and policy space to effectively regulate capital at both ends.

\section{Countervailing Monetary Power}

The EMDs that were able to reregulate cross-border finance and maintain the related requisite policy space under the global economic governance institutions were able to do so, in part, by exercising countervailing monetary power. As we have seen in chapter 1 , countervailing monetary power can operate in two arenas. At the national level, countervailing monetary power can be used by a country to overcome political and economic forces and counter the structural power of global capital markets. At the international level, countervailing monetary power can be used by relatively weaker states to counter the realist power and institutions crafted by stronger states.

On the home front, EMDs that were successful in regulating cross-border finance exerted countervailing monetary power supported by five pillars: domestic institutions that allowed financial authorities to regulate flows in a timely and countercyclical manner, the backing of exporters who were more concerned about the exchange rate than access to global finance, the backing of workers (and worker parties) motivated by job security over short-term consumption benefits, the backing by a general public haunted by the collective memory of past crises, and the ability to translate economic ideas to decision makers and the general public. Countries that were not able to put adequate regulations in place did not have the support of enough of these five pillars to overcome the traditional obstacles to regulation.

First, in both Brazil and South Korea, there were institutions in place that allowed the governments to channel new ideas and political backing into central bank policy. Although both countries had independent central banks, they had institutions that gave financial authorities a partial say as well. Second, in Brazil, exporters were more sensitive to the exchange rate than to a loss of international financing because Brazil offered several public and privately regulated options for finance. Thus, when the exchange rate rose during a surge in inflows, 
exporters were more disposed to regulating finance for material reasons. When exporters rely on international finance for the majority of their financing needs, regulations on the inflow of capital will hurt their ability to raise capital and strengthen the political alliance between industry and finance, which will be opposed to regulation. Third, in Brazil organized labor (which forms the core of the party in power) was more concerned that exchange rate volatility would threaten their employment prospects than they were about the temporary benefits of exchange rate appreciation during a surge. Fourth, in both Brazil and South Korea, policymakers drew on the collective memory of financial trauma to gain political backing for their actions. Both countries had been plagued with severe crises that are very alive in the memories of workers and citizens. Under normal circumstances, workers and citizens enjoy exchange rate appreciation because it allows them to purchase more goods. In these two countries, however, workers and citizens knew too well that exchange rate pressure and credit bubbles can lead to lost jobs, high debt, and inflation. And fifth, policymakers had the idea of expanding the mitigation toolkit to include cross-border financial regulations and were able to gain support for their actions by framing it in the new economics of capital controls (see chapter 3). In Brazil, the Finance Ministry, although coming from a Minskian developmentalist framework, reframed its rationale for regulation to the Central Bank as "externalities" to conform to the language of the Central Bank. In South Korea, Hyun Song Shin and others framed regulations as pragmatic approaches to stem systemic risk at the major source-cross-border banking operations. Moreover, when South Korea spoke about its measures to the world, it defined them as macroprudential regulations on the foreign exchange derivatives market, not as capital controls on global finance (as Brazil had).

Many EMDs, especially the BRICS, also led a charge in global economic governance institutions to expand or preserve their policy space to regulate crossborder finance and to gain the cooperation of the source countries of the capital flow. As summarized in table 9.1, the global statecraft aspects of countervailing

TABLE 9.1 Pillars of countervailing monetary power

\begin{tabular}{ll}
\hline National level & Institutions for timely countercyclical regulation \\
& Less reliance on global finance \\
& Strong organized labor and affiliated parties \\
& Evocation of the collective memory of past crises \\
& Reframing control as macroprudential regulation \\
& Larger levels of preexisting policy space \\
& Exerting market power \\
& Creating coalitions \\
& Leveraging fragmentation \\
& Leveraging new ideas \\
\hline
\end{tabular}


monetary power also have five pillars: nations need policy space to regulate under global economic governance institutions, nations are more apt to gain policy space as they gain market power in the global economy, nations can concentrate such market power by forming coalitions, these coalitions can leverage the fragmentation of global governance to their benefit, and they can leverage global governance through the translation of new economic ideas.

EMDs were able to obtain or preserve the most policy space at the WTO and the G20. In both these institutions, at least on paper, members adhere to a one country-one vote system that operates by consensus. Of course, equal voting power does not translate fully into more power. Perhaps even more important than the institutional structure in these two forums was the ability of EMDs to use their increased market power to the most advantage within the institutional structures. At the WTO, Brazil, South Africa, India, and China (Russia did not join the WTO until August 2012) all had large markets that were coveted by the industrialized countries. In a one country-one vote system operating by consensus, these countries were able to employ intraforum leverage significantly-they would not liberalize services unless the industrialized countries did so on agriculture. What is more, EMDs formed numerous coalitions at the WTO. At the G20, they were able to do the same. BRICS formed a coalition within the G20 and were able to employ intraforum leverage, getting concessions in exchange for being willing to discuss EMD participation in the euro crisis. By negotiating an alternative BRICS reserve pool and development bank on the sidelines of the G20, they were also able to employ extra-forum leverage to get the G20 to acknowledge the negative spillovers of the monetary policies of the industrialized countries.

The increasing EMD market share also played a role at the IMF. In contrast to the late 1990s, when all BRICS countries (except China) had undergone an IMF country program and they collectively had 9 percent of global GDP, in 2012 no BRICS had a country program and they represented 34 percent of GDP. The IMF quota system had been improved in this light but only slightly, and some reforms were yet to get through the US Congress during the proceedings of the IMF institutional view. On an institutional level, significantly, the IMF management and staff took an initial position that already met the EMDs halfway on capital account regulation. The spirit of new thinking at the IMF and the diffusion of new ideas throughout the staff were key on this issue. This was a complete contrast to the 1990s, when the IMF management and staff and the industrialized countries were all pursuing capital account liberalization. This time, the management and staff were in charge of setting the agenda and endorsed the kinds of capital account regulations pursued by EMDs. Moreover, the industrialized countries had 
been nudged toward viewing more favorably capital account regulations used for prudential reasons, although they were still vehemently opposed to regulations used to mobilize domestic finance through a heavily managed exchange rate regime. BRICS were able to use intraforum leverage by strategically siding with the IMF staff during key parts of the process. They also employed extra-forum leverage by using their gains on capital account regulation made at the G20 to wedge their positions into the IMF deliberations.

Of course, the distribution of power and institutional structures also explain why EMDs didn't fully achieve their goals and, in some cases, lost more policy space. At the WTO, smaller states had to liberalize much of their financial services sectors. At the IMF, the industrialized countries were able to temper language that called for the industrialized countries to regulate capital flows at the source of the capital flow cycle. The most significant case is the use of FTAs and BITs by the United States. Bilateral negotiations between a large economy and a small one are tilted in favor of the large economy because the large economy can make agreeing with its objectives a condition of access to its markets. The United States was able to put such conditions into its FTA with Chile, even though Chile had managed to avoid such conditions in its treaties with Canada and the European Union. In contrast, South Korea had a larger economy than Chile and had many sectors that the United States wanted access to. As a result, South Korea was able to use intraforum leverage and make maintaining its innovative law granting its financial authorities the ability to put capital account regulations in place a condition of entering into an FTA with the United States.

\section{Policy Recommendations for Countervailing Monetary Power}

EMDs can put in place several policies and strategies that can accentuate their ability to exert countervailing monetary power at the national and international levels. There are ten policies or strategies that may help these states regulate the structural power of capital markets in their own economies and maintain or expand the policy space for regulation and cooperation in global economic governance institutions.

1. Put in place permanent but countercyclical regulations on cross-border finance.

Both Brazil and South Korea have legislation in place that grants the finance ministries the authority to make quick decisions on the regulation of cross-border 
finance. This is politically important because it avoids wasting time on major legislative battles in the midst of a boom, when the political forces against regulation may be strongest. Such regulations should be made permanent but should be countercyclical in nature. The regulations should be tightened when there is a rise in inflows or systemic risk related to cross-border finance, and they should be eased as capital becomes scarcer. Countries also have to build the institutional capacity to fine-tune regulations as the capital cycle persists. Both Brazil and South Korea were constantly adjusting their regulations on inflows (see chapter 4). That said, it appears that the capacity of South Korea to regulate flows is the stronger of the two because South Korea did not experience a sudden stop in capital flows, as Brazil and other nations did in 2014.

2. Foster institutions to diversify sources of finance.

Economic diversification is, of course, the key to long-run growth and development. If such diversification is fueled by a variety of financing sources, both public and private, then sectors in the industrial economy will not be as tied to the international financial sector. This is important for economic reasons-the real economy will be less susceptible to the surges and sudden stops of international finance. It is also very important politically-industry may be less likely to collude with international finance against regulation because it will be more sensitive to exchange rate volatility than to its links to the international financial sector. The development of domestic bond markets is essential here, but not enough. In early 2014, 50 percent of domestic debt in EMDs was held by foreign investors and can thus be subject to surges and sudden stops as well. Reviving national development banks is yet another way to provide domestic financing, as in Brazil, along with regulations requiring the private banks in the country to earmark certain types of long-run investments on favorable terms.

3. Foster institutions to enable organized labor to collectively bargain and engage in political parties. Leaders should emphasize job security over exchange rate benefits.

If there is a relatively small industrial working class and the workers are not organized, politics may favor households and consumers driven by consumer benefits rather than job security. Organized labor tends to concentrate on job security and wages, and sees exchange rate fluctuation as a threat to those objectives. Households and consumers, in the short term, often see exchange rate appreciation as an income and sometimes as asset boost and thus organize against regulation. Therefore organized labor should be supported to this end.

4. Engage with the general public to evoke the collective memory of past financial crises. 
Financial crises have been associated with significant trauma. Remembering this trauma can help the general public take a longer-run view of certain policy outcomes. As we have seen, the collective memory of past financial crises really resonates in Brazil and South Korea-two nations that have been plagued with severe crises. The general public can sometimes be re-oriented from what might seem rational in the short term toward longer-run objectives. That is, lack of regulation of capital flows may benefit individual citizens in the short term through an appreciated exchange rate, but if the public is reminded that the financial amplification effect can kick, with the rising exchange rate tied to job losses and its subsequent fall causing massive inflation, citizens are more apt to support the regulation of cross-border finance.

5. Reframe the need to regulate cross-border finance at home and abroad.

It is important to devise country-specific regulations that target where the crossborder financial risk is coming from. Sometimes it will be the foreign exchange (FX) derivatives market, the bond market, equities market, or the currency market itself. Sometimes hard, quantity-based capital controls are the best way to prevent and mitigate the risk associated with cross-border finance; at other times, price-based second-generation regulations are more appropriate. Increasingly, third-generation regulations on the FX derivatives market, on highly interconnected banks, and other sectors may be more appropriate. This family of regulations are better referred in a broader sense for economic as well as political reasons. If the measures are reframed as regulations to maintain stability for productive growth that are inherently corrective, rather than distortionary, such framing may go a long way to making them acceptable at home and abroad. Brazil branded its regulations in this manner to gain the acceptance of the Central Bank. Yet when Brazil announced its policies to the world at large, it called them "capital controls" to stem a "tsunami" of money from US monetary policy. This put the investment community on alert, tempting investors to exercise their exit option. Indeed, as capital flowed out of Brazil in 2013, many investors, when asked to come back to Brazil, asked for a guarantee against future capital controls. In contrast, South Korean authorities, both internally and externally, framed and referred to their policies as macroprudential policies aimed at stemming systemic risk being transmitted through cross-border banking. This conformed to the language of the new economics of capital controls and the new lingo in the global financial regulatory reform circles_-and put investors and the industrialized countries alike at ease.

6. Build on coalitions of market power.

The BRICS coalition and other EMD coalitions in the WTO can be built on and better coordinated to preserve and gain the policy space for regulation in global 
economic governance institutions. The outcomes of agreements are often determined by the distribution of market power among parties to the agreementthose having the most market power obtain the largest benefits. EMD market power has increased significantly since 2000, and consolidating that power via coalitions can help EMDs leverage their objectives in a more optimal manner.

7. Continue to push for quota reform at the IMF.

As we have seen, the more say that EMDs have in deliberations, the more their policy objectives will be achieved. As EMDs, in general, and the BRICS coalition, in particular, gain economic momentum, they should strive to increase IMF quotas along with those increases in economic output.

8. Continue to build alternative institutions, and leverage those institutions for a more balanced global system.

In addition to quota reform at the IMF, EMDs should continue to develop and expand alternative institutions that better serve their mission and needs. This will not just help EMDs provide each other with the public goods they are not obtaining through the traditional international financial institutions. For example, the creation of a BRICS development bank and a BRICS reserve currency pool helped those countries to employ extra-forum leverage in the traditional institutions to achieve their goals and to balance quota systems.

9. Reform the trade regime for stability-supported trade and investment.

When there is national legislation in hand, it is easier to leverage such legislation in international trade and investment negotiations. At the WTO, a nation can make notifications that such new regulations are in place and that the member country sees them as prudential in nature and thus falling under the WTO exception for prudential measures. In further negotiations, such regulations should not be offered in a future positive list for liberalization; the country should attempt to have them carved out of FTAs and BITs, as Chile did in its FTAs with Canada and the European Union, and South Korea has been able to do in its FTA with the United States. For nations without regulations already in place, strong balance-of-payments exceptions and prudential measure exceptions are needed in future treaties and probably should be inserted into past or renegotiated treaties.

10. Devise and propose coordination mechanisms to regulate cross-border finance on both ends.

The global financial crisis has reinvigorated the rationale for cooperation in the regulation of cross-border finance on both ends. For pragmatic reasons, EMDs 
alone cannot carry the burden of regulating flows, given their institutional capacity relative to the size and sophistication of global capital markets. Advances in economic theory also justify regulating cross-border finance at both ends. Although there are sophisticated new rationales for regulating at both ends, a clear set of policy proposals regarding what that cooperation might look like is still lacking. Previous proposals have included controls on outflows of capital in source countries and an ad hoc cooperation mechanism based on the global anti-money laundering regime (see Helleiner 2002). Recent articulations have suggested that, under the auspices of the G20, the cooperative in cooperative decentralization be emphasized. At the G20, all countries agreed to coordinate their financial regulatory reform efforts so as not to cause negative spillover impacts caused by the actions of individual countries. As noted in previous chapters, if the G20 simply coordinated and mandated regulations on FX derivatives for banks and nonbanks, such an action would go a long way toward achieving cooperation at both ends. At this writing, there has been little official coordination, and domestic regulation has been driven by domestic politics. The truth is no clear and coherent proposals with a particular emphasis on the instability of cross-border finance have come forth in the wake of the crisis. This is an important topic for many of the new institutions to take up, and for the UNCTAD and IMF as well.

The countries that were most successful in the post-crisis period had some combination of these ten policies, which are largely drawn from the ten tenets of the theory of countervailing monetary power outlined in this book. That said, with perhaps the exception of South Korea, no country has used such policies to their full potential. In late 2013 and early 2014, when the US Federal Reserve Bank began moving away from its loose monetary policy, there was a sudden stop in many of the countries we have discussed. At this writing, it appears that South Korea will prove to be the most resilient during the sudden stop; however, the measures used by Brazil, Chile, and South Africa do not seem to be enough to stem the outflow of capital and subsequent financial fragility. These nations needed a stronger policy_and coordination with the West.

According to most accounts, at least five of today's EMDs will be among the ten largest economies in the world by 2050. Most projections put China, India, Brazil, Mexico, and Indonesia among the largest economies in the world at that time (for projections and a review of the literature, see Dadush and Shaw 2011). If these nations continue to exercise countervailing monetary power to craft national policy and to balance global economic governance institutions, they may be able to achieve a more stable international monetary system than the one that has been orchestrated by the great powers since the demise of the Bretton Woods system. For a truly balanced system, they will need to remember what it was like to be vulnerable to the economic policies of large powers. Thus, on the 
way up, they need to craft new institutions and reform the traditional ones to enable countries to maximize the benefits and mitigate the risks of cross-border finance. If they follow the path laid by the great powers since the demise of Bretton Woods, there may be even more instability and polarization in the future world economic system. It is my hope that this volume can shed light on how weaker countries can overcome many obstacles to regulating finance at the national and global levels. 